\title{
Citizen's Adoption Of Mobile Land Record Information Systems (mLRMIS): A Case of Pakistan
}

\author{
Babur Hayat Malik \\ Cai Shuqin \\ School of Management, \\ Huazhong University of Science and Technology, Wuhan China \\ Abdul Ghaffar Mastoi \\ School of Public Administration, \\ Huazhong University of Science and Technology, Wuhan China \\ Ahmed Hussein Alsherbiny Ahmed Ghais \\ School of Management, \\ Huazhong University of Science and Technology, Wuhan China
}

doi: 10.19044/esj.2016.v12n5p393 URL:http://dx.doi.org/10.19044/esj.2016.v12n5p393

\begin{abstract}
By implementing a prolonged social cognitive theory (SCT) this article investigates factors including outcome expectation, affect, anxiety, self-efficacy, social influence, trust, facilitating conditions, e-satisfaction, information quality and e-service quality impacting citizen' $s$ intention to adopt a mobile based e-government system called mobile Land Record Information Systems (mLRMIS) with respect to Pakistan. The prolonged social cognitive theory (SCT) was actually affirmed by analyzing gathered data periodically accumulated over time from 10 different cities in Pakistan. Verifiable results of the proposed model represented mutual significance of relationships of 12 hypothesized relations between 10 different types of constructs. Only a few studies have previously used SCT model to investigate the adoption of an e-government system globally while in case of Pakistan it is the first ever study using SCT model to figure out the adoption of an e-government system. Outcome significance and digital policy substance exhibited in this article can assist e-government planners and practitioners to reform up quality and effectivity of mLRMIS system. This research also contributes to elevate relevant awareness and utilization of mLRMIS system.
\end{abstract}

Keywords: E-government, LRMIS, Adoption, SCT, Citizens, Pakistan 


\section{Introduction}

A lot of governments have meliorated the frameworks and services to serve up their citizens (Kim, Pan and Pan; 2007). The awareness of electronic government (e-government) is a policy shift adopted by governments to achieve more service oriented functions and to be refocused towards implementation of the modern digital services through one stop spots of online access for citizens (Anthopoulos, Siozos and Tsoukalas; 2007). E-government offers overt advantages to governments, organizations and professionals (Venkatesh, Sykes and Venkatraman; 2014) but actually it is citizens who are anticipated to be benefited (Jaeger, 2003). As governments are interested to acquire modern e-government systems increasing to deliver better services to their citizen hence it is a dire need to actually evaluate the relevant efforts that could investigate those systems effectiveness in terms of their adoption (Wang and Liao, 2008). The most of the research do not specifically focus on developing countries (Venkatesh et al., 2014) only besides few studies (Rana, Dwivedi; 2015, Williams and Lal; 2013, Rana, Dwivedi, Williams and Weerakkody; 2014) Land Record Management Information System (LRMIS) is an e-government system which is designed to digitalize the land record and different issues related to land administration in Punjab; biggest province of Pakistan w.r.t. population. Citizens can observe their land record online anytime regardless of time and location by entering some of their personal information on the web. It provides a lot of advantages to the citizen and in future more would be added. Mobile information systems are designed specifically for mobile devices and used often for education, banking, entertainment, health and other user-centric online mobile-based demands. The adoption of sophisticated mobile services observed slower than expected regardless of availability of huge number of services. Mobile government services are crucial systems/applications of mobile based communications in egovernment area. Many researches have noticed that mobile government services comparisons and innovations could be of tremendous value to modern mobile application/services. Critical differentiation between mobilegovernment systems/services and traditional e-government systems/services is that while traditional applications/services permit more non-mobile applications/services to deliver while mobile-government systems/services/applications permit more mobile-based communication component relatively. Citizens easily may engage and e-participate in discussions of different topics and issues with increasing rate of frequency, improving mobile-based communication skillfulness, enhancing mobilebased communications flexibility, sharing their government's modern digital image and receiving more custom-make services while enjoying high accessibility of relevant services (E-Government, 2010). Adopting successful 
and fruitful strategies to promote mobile-based services originates from very good understanding related to users' expectations and their preferences of mobile-based services. Main determinants for the success of mobile systems/services/applications need to identify real potential and actual customers for determining how they are being influenced and how they actually behave and to disclose what they actually expect (S.J. Barnes, 2000). Eventually it is necessary to know the potential mobile users and their needs to develop mobile based services (J. Krogstie, 2001).

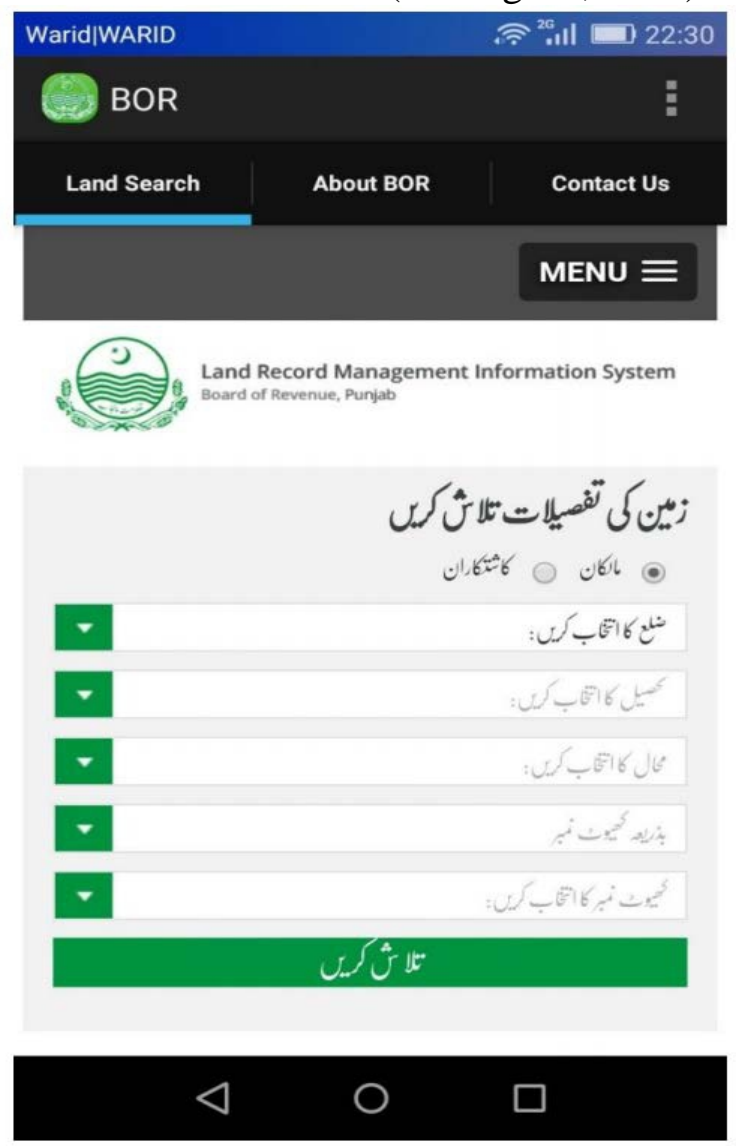

Fig. 1: Mobile application of Land Record Management Information Systems

In above mentioned Fig. 1, mobile application of Land Record Management Information Systems is shown. Reforming land records and the usefulness of land markets in Pakistan is a top priority interest for Pakistan Government in view of the wider circle of E-Government at both the central and local levels. In case of Punjab it has a total area consisting of 205,345 square kilometers being most populated province of Pakistan with 80.7 million inhabitants (55.9\% of Pakistan' s total population). Land Record 
Computerization as always a vital technical factor of the strategy for Egovernment while focusing requirements to be evenly delivering on improved digital service delivery to the citizen. Land Record Information Systems (LRMIS) supervised and supported under World Bank as some of the details provided by World Bank website can be seen in the following table (The World Bank). In this article we actually try to investigate the citizen' s behavior to adopt a mobile based information system known as mobile Land record information systems based on SCT in context of knowing that the SCT is one of the most significant theories of human behavior so it would be very useful to investigate the adoption of the LRMIS using a model based on the SCT by validating a prolonged version of SCT. The lack of use of this model in the e-government adoption research is one of the motivations to use this model as it encompasses all suitable and significant constructs which exhibits relevant and useful factors to actually understand citizen's adoption behavior. The additional constructs like social influence, facilitation conditions and trust are added to this model too.

\section{Literature review}

Many renowned technology acceptance and success models exist besides the theory of reasoned action (Fishbein and Ajzen, 1975), the technology acceptance model (Davis, 1989), the theory of planned behavior (Ajzen, 1991), the innovation diffusion theory (Rogers, 1995), the IS success models (DeLone and McLean; 1992 and 2003) and the unified theory of acceptance and use of technology (UTAUT) (Venkatesh, Morris, Davis and Davis; 2003) which have been studied across several researches in egovernment (mobile or non - mobile ) contexts in developed and developing countries. The social cognitive theory (SCT) (Bandura, 1986) has not been fully followed in many studies yet to investigate the adoption of any mobile based e-government systems as some of its constructs while in their original style such as anxiety and self-efficacy and some other in their correspondent style like outcome expectations (as that of usefulness (Davis, Bagozzi and Warshaw; 1989, Compeau and Higgins; 1995) and affect (as that of attitude towards use of technology (Venkatesh et al., 2003) have been followed in a lot of researches in e-government adoption to develop respective integrated research model on e-government adoption but a few studies (Sahu and Gupta; 2007, Loo, Paul, Yeow and Chong; 2009) have partly employed the SCT or some of its constructs. Like in case for investigating the acceptance of Malaysian government multi-purpose smartcard application; Loo et al. (2009) added in his proposed model anxiety as the direct factor of intention to use the system. In studies related to e-government in Malaysia results exhibited that responder' s while using e-government systems/applications 
for example Driving License (DL) and MyKad National Identity Card (NIC) were uninterested in their anxiety factor and their consequent intentions to use relevant systems. Sahu and Gupta (2007) while investigating the user's acceptance of Indian Central Excise system proposed an incorporated research model by selecting 2 constructs (self-efficacy and anxiety) from SCT. Moreover studies like Carter, Schaupp and McBride (2011) and Fotland (2012) has also investigated the impact of anxiety on behavioral intention. Other additional construct is Trust which is a critical factor for success of a productive e-Government systems considering privacy as the main ingredient in citizen' s trust in e-Government system/service (Kim et al., 2009). Mcknight et al. (2002) suggested a model of e-commerce consumer trust examining that trusting beliefs directs to trusting intentions impacting trust related behavior (i-e satisfaction). Customer trust is a set of beliefs owned by online customers involving clear aspect of e-supplier and the future viable behavior of the e-supplier (Coulter and Coulter, 2002). Lee and Lin (2005) advocated that trust inspires online purchasing and affects consumer mentality towards buying from t-retailers. In the U.S Kim et al. (2009) performed a longitudinal study and discovered that online consumer' $s$ trust is substantially associated to loyalty. Trust in eGovernment discloses that citizens' trust in the government organization decreases their beholding of the risks to use e-Government systems/services (Belanger and Carter, 2008). Due to fast internet penetration internet is a huge origin and source of vast information and related services; a wellcrafted and well developed e-Government website or mobile application has become substantially a need of consumers to access respective public related information and to enhance their participation. Government websites would be able to serve as a means and tool to communicate and attached to public relations for relevant general audience public. Information and data would easily be handled, shared with and posted to external stakeholders (Moon, 2002). Henry (2006) described web accessibility as more users to use, perceive, understand, interact and navigate with the web /mobile services. International Standards Organizations (ISO) definition of accessibility is "the usability of a product, service, environment or facility by people with the widest range of capabilities" . Gummerus et al. (2004) describes the user interface as the medium through which customers are in touch with the eservice provider. Park and Kim (2003) discovered that the quality of the user interface impacts directly on customer satisfaction since it gives physical symptoms of the service provider's proficiency and to facilitate unstrained use of the service. Gummerus et al. (2004) pointed out that quality of user interface is assumed to directly affect trust. Roy et al. (2001) discovered that interface design, ease of navigation and user guideline really affects 
consumer trust. Perceived service quality has two aspects; the technological which is related to what to deliver and the functional aspects which are associated to the service delivery. Feedbacks speed, updates and service effectiveness etc. are attached to the technical quality (Rust and Lemon, 2009). Product/service quality is the customer perception of the quality of related information about the product/service which is offered by website/systems (Park and Kim, 2003). Website/mobile service ingredients quality has been discussed as an antecedent of trust of online customer (Mcknight et al., 2002). Park and Kim (2003) discovered that the information quality impacts customer intentions/satisfaction directly. Chen (2008) investigated the issues of consumer acceptance of m-payment using TAM and IDT models. The outcome showed that consumer acceptance of mpayment was determined by 4 factors: Perceived usefulness (PU), perceived ease of use (PEOU), perceived risk (PR) and compatibility. Luarn et al. (2005) investigated the factors determining users' acceptance of mobile banking using Extend TAM with 3 additional constructs: perceived selfefficacy, Perceived Credibility and perceived financial cost. The results support strongly the properness of using this extended TAM to know the intentions of people towards use of mobile-banking systems/services.

\section{Research model development and hypotheses}

Principally abstractive elaboration for this study is based on the SCT model. Bandura (1986) suggested it as one of the most effectual theories of human behavior. Compeau and Higgins (1995 and 1999) utilized and broadened SCT to the context of computer practicality. Theory primarily examined computer usage but the characteristic of the proposed research model and the implicit nature of theory permit it to be broadened to acceptance and use of an e-government system (i-e an information system like LRMIS). Important reasons to utilize the SCT as a base model are two. First it suggests all evidential variables along with investigating them as factors accountable to adopt an e-government system. Second reason is that there is still a huge gap to study while using this theory in research area like information systems especially e-government systems to grasp the prominence of its variables. Based on some legitimate explanations in our proposed research model we included 3 constructs social influence, trust and facilitating conditions. Social influence is the level to which an individual perceives that valuable related other people believe that he or she should use the system (Venkatesh et al., 2003). Adoption of an e-government system by a single person can be impacted substantially by his or her valuable other people in that society so it is worthy to adjust social influence with basic SCT model. Social influence will be substantial in figuring out the adoption of the mobile LRMIS using in the proposed research model because this e- 
government mobile system has mainly been designed keeping citizen's aspects in mind and social nature of mLRMIS system as there is a deficiency contextual variables in the SCT.

Table 1: Hypothesis Definitions \& Supporting studies

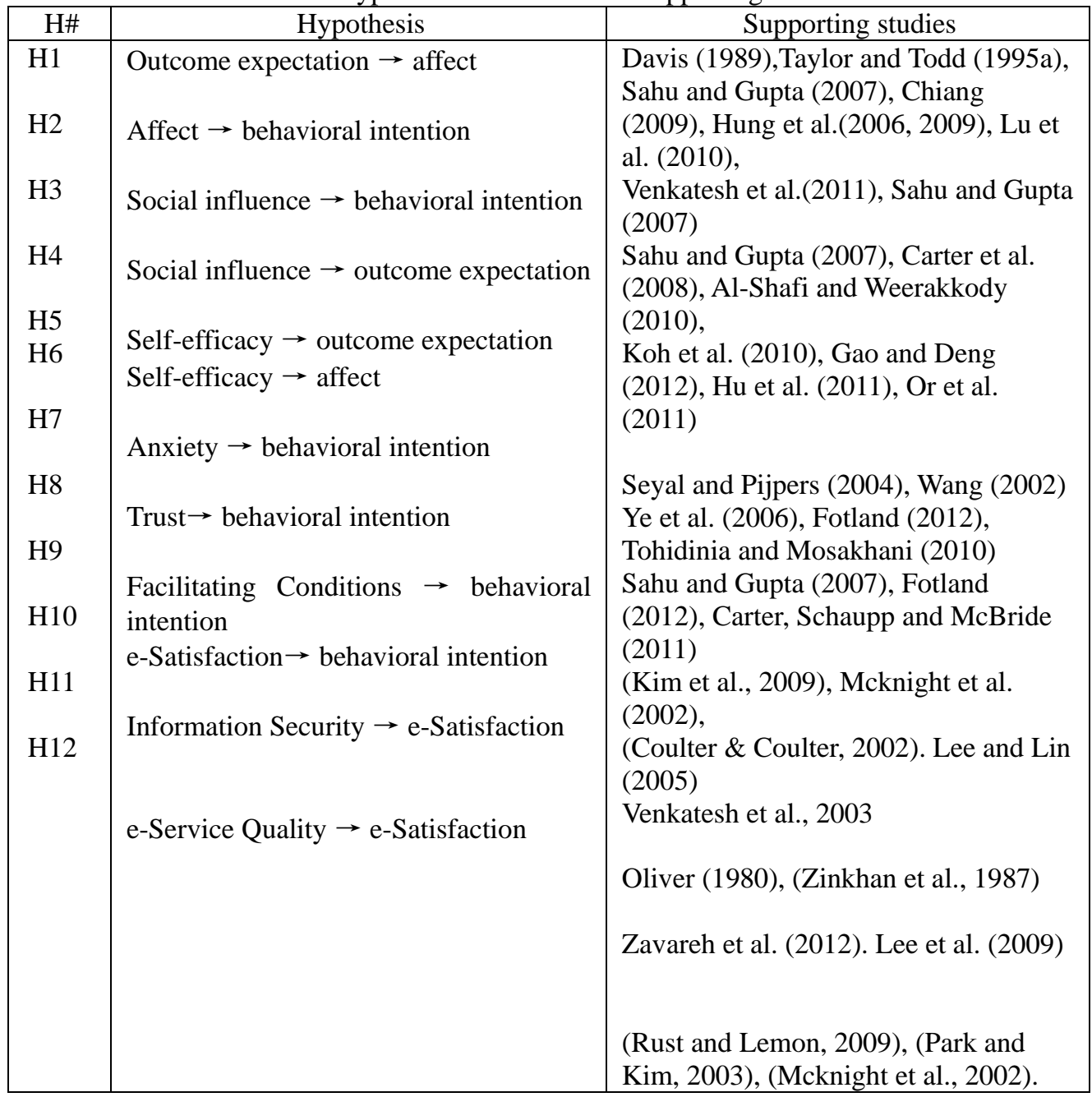




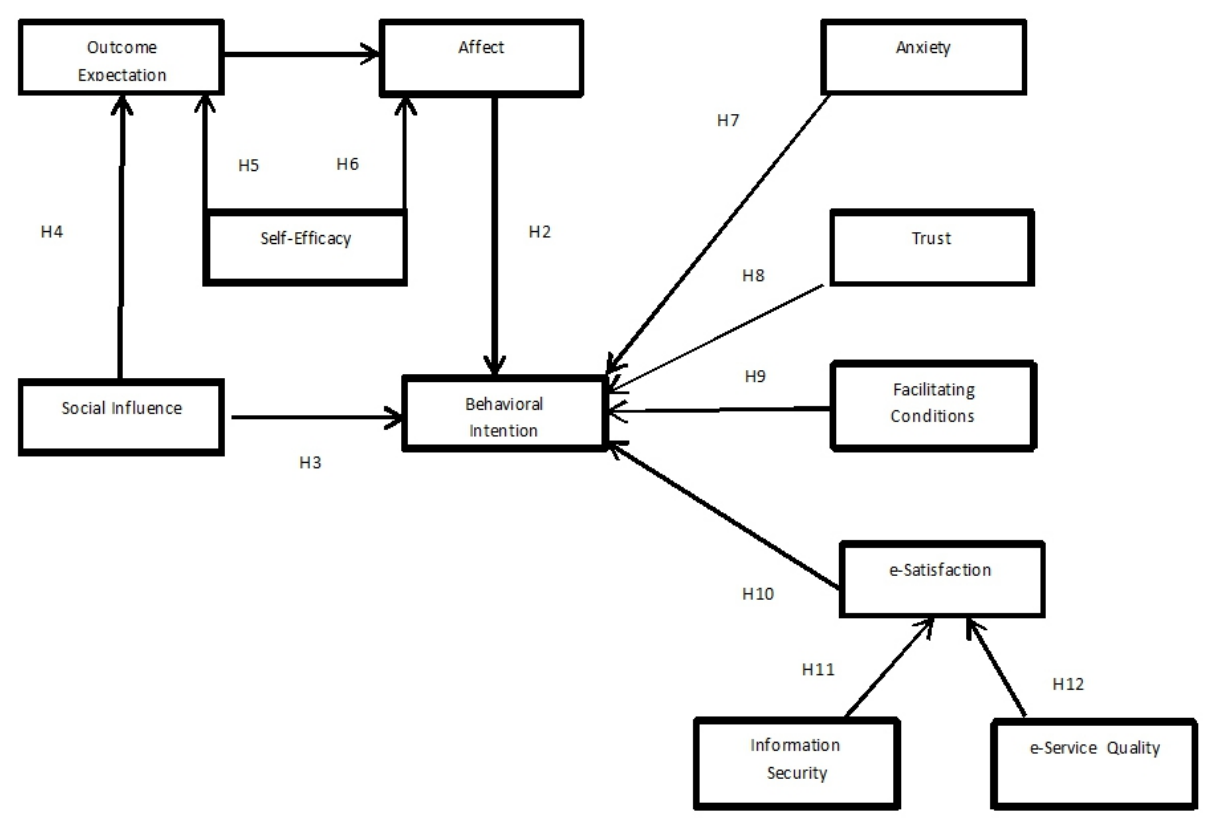

Fig. 1: Proposed Res earch Model.

Fig. 1: Proposed Research Model.

\section{Research methodology}

To investigate e-government system adoption of the mobile based LRMIS we believed that survey is a proper research method. Our questionnaire was composed of total 27 questions including 10 questions from respondent's demographic characteristics and remaining 17 questions on 9 different constructs of the proposed research model. Multiple-type questions, close-ended and seven-point Likert scale type questions. For all non-demographic questions Likert scales $(1-7)$ with covering from

'strongly disagree' to 'strongly agree' was used. Appendix (A) lists all the items for the constructs used in this study.

Sample of research comprised of responders from different cities of Pakistan including Lahore, Gujranwala, Gujrat, Wazirabad, Sialkot, Jhehlum and Kharian. Total 600 questionnaires were spread out to respondents. Responders were exhibited and detail demonstrations were given about mobile based LRMIS system. Total of 395 questionnaires returned. Further inspection of questionnaires showed that 95 among them were partly filled and hence rejected. 300 valid responses were selected for the empirical analysis to measure adoption of mobile based LRMIS. A brief introduction were given to all of the respondents about Mobile based service of LRMIS. Some of them already used it and some used it for the first time. 


\section{Research findings}

5.1. Respondents' demographic profile

In Table 2 we analyzed the demographic data of respondents. Questionnaire feedbacks showed the average responder's age from 20 to 50 with males accounting for 75 percent of the sample and 25 percent were female. The most of sample population (i.e. 70\%) are from student community along with a some representing from private and public sector employees (i.e. 30\%). More than $85 \%$ of the total population is having a minimum of graduation degree or in studying at graduation level in case of educational background/qualification of responders. Internet/computer knowledge and awareness of the responders can be observed from their very high Internet/computer related experience percentage $(\approx 98 \%)$. Hence it is suggested and believed that the sample of responders were to be the bestfitted potential adopters of the LRMIS systems.

Table 2: Demographics of responders

\begin{tabular}{|l|c|}
\hline Variable & Count (\%) \\
\hline Gender & $225(75 \%)$ \\
\hline Male & $75(25 \%)$ \\
\hline Female & \\
\hline Age (in years) & $3(1.0 \%)$ \\
\hline$<18$ & $227(75.7 \%)$ \\
\hline $19-30$ & $37(12.3 \%)$ \\
\hline $31-40$ & $27(9.0 \%)$ \\
\hline $41-50$ & $6(2.0 \%)$ \\
\hline Over 50 & \\
\hline Education & $20(6.66 \%)$ \\
\hline Senior high school and under & $80(26.66 \%)$ \\
\hline Undergraduate & $200(66.68 \%)$ \\
\hline Graduate and higher
\end{tabular}

\subsection{Descriptive statistics}

Table 3 shows means, standard deviations and ranges for all eight variables. Overall high and individual factor' $s$ means for many of the constructs shows that responders respond favorably to the all measurements directly or indirectly associated to behavioral Intention. Using AMOS in Table 4; squared pair correlations of potential variables computed are shown. 
Table 3. Mean, S.D. , Cronbach's alpha of Constructs

\begin{tabular}{|c|c|c|c|c|}
\hline Constructs/Measurement & $\mathrm{N}$ & Mean & S.D. & Cronbach's alpha \\
\hline Outcome expectation (OE) & 300 & 5.14 & 1.10 & 0.763 \\
\hline OE1 & 300 & 5.13 & 1.29 & \\
\hline OE2 & 300 & 5.14 & 1.27 & \\
\hline OE3 & 300 & 5.17 & 1.21 & \\
\hline Affect (AFT) & 300 & 5.11 & 1.11 & 0.711 \\
\hline AF1 & 300 & 5.09 & 1.41 & \\
\hline AF2 & 300 & 5.14 & 1.33 & \\
\hline AF3 & 300 & 5.11 & 1.38 & \\
\hline Self-efficacy (SE) & 300 & 5.09 & 1.21 & 0.639 \\
\hline SE1 & 300 & 5.11 & 1.37 & \\
\hline SE2 & 300 & 5.08 & 1.46 & \\
\hline Social influence (SI) & 300 & 4.65 & 1.24 & 0.708 \\
\hline SN1 & 300 & 4.72 & 1.51 & \\
\hline SN2 & 300 & 4.91 & 1.46 & \\
\hline Anxiety (ANX) & 300 & 4.01 & 1.21 & 0.729 \\
\hline ANX2 & 300 & 4.11 & 1.61 & \\
\hline ANX3 & 300 & 3.79 & 1.69 & \\
\hline ANX4 & 300 & 4.11 & 1.43 & \\
\hline Trust(TR) & 300 & 5.33 & 1.12 & 0.753 \\
\hline TR1 & 300 & 5.35 & 1.34 & \\
\hline TR2 & 300 & 5.31 & 1.31 & \\
\hline Facilitating Conditions(FC) & 300 & 5.24 & 1.11 & 0.779 \\
\hline FC1 & 300 & 5.21 & 1.41 & \\
\hline FC2 & 300 & 5.27 & 1.33 & \\
\hline e-Satisfaction(SAT) & 300 & 5.19 & 1.10 & 0.778 \\
\hline SAT1 & 300 & 5.23 & 1.32 & \\
\hline SAT2 & 300 & 5.24 & 1.31 & \\
\hline Information Security(I-Sec) & 300 & 4.99 & 1.09 & 0.766 \\
\hline I-Sec 1 & 300 & 4.98 & 1.09 & \\
\hline I-Sec 2 & 300 & 4.97 & 1.11 & \\
\hline I-Sec 3 & 300 & 4.98 & 1.32 & \\
\hline I-Sec 4 & 300 & 5.11 & 1.31 & \\
\hline e-Service Quality(e-SQ) & 300 & 5.15 & 1.14 & 0.789 \\
\hline SQ1 & 300 & 5.11 & 1.34 & \\
\hline SQ2 & 300 & 5.18 & 1.29 & \\
\hline Behavioral intention (BI) & 300 & 5.27 & 1.21 & 0.781 \\
\hline BI1 & 300 & 5.29 & 1.45 & \\
\hline $\mathrm{BI} 2$ & 300 & 5.27 & 1.41 & \\
\hline BI3 & 300 & 5.25 & 1.39 & \\
\hline
\end{tabular}

Table 4 shows results as AMOS is used to compute pairwise Squared correlations for different variables. 
Table 4. CFA model based (Measurement model estimations)

\begin{tabular}{|l|l|l|}
\hline Fit index & CFA model & Recommendation \\
\hline Chi-square & 218.987 & N/A \\
Degree of freedom (DF) & 99 & N/A \\
P & 0.001 & $>0.05$ \\
Chi-square/DF & 2.211 & $<2.500$ \\
GFI & 0.899 & $>0.80$ \\
AGFI & 0.895 & $>0.80$ \\
CFI & 0.896 & $>0.80$ \\
RMSEA & 0.051 & $0.05<$ RMSEA $<0.09$ \\
& & \\
\hline
\end{tabular}

\subsection{Measurement model}

By using (CFA) confirmatory factor analysis discriminant validity and convergent of the scales were reported. To avert any contact between 2 models considering measurement errors quantifications characteristic of the model is assessed antecedent in testing of structural model. To determine Uni-dimensionality a correlation matrix of a 9 factor model (Outcome expectation, Affect, Self-efficacy, Social influence, Anxiety, Trust, Accessibility, Service Quality and Behavioral intention) was standardized and evaluated. Internal consistency and fit statistics were calculated to mark reliability, fitness of model and discriminant validity. Fit statistics are shown in above mentioned Table 4. In Table 5 we show the composite reliabilities, factor loading and variance-extracted estimates. Relevant loadings were discovered significant. Composite reliabilities similar to Cronbach's alpha were calculated as surpassing the minimum range of 0.70 for all underanalysis constructs but self-efficacy (CR 0.634). The reliability exhibits severe internal level consistency for 9 constructs and adequate level for selfefficacy. 
Table 5: Confirmatory Factor Analysis

\begin{tabular}{|c|c|c|c|}
\hline Constructs & Factor Loading & Composite Reliability & $\begin{array}{l}\text { Variance Extracted } \\
\text { Estimates }\end{array}$ \\
\hline 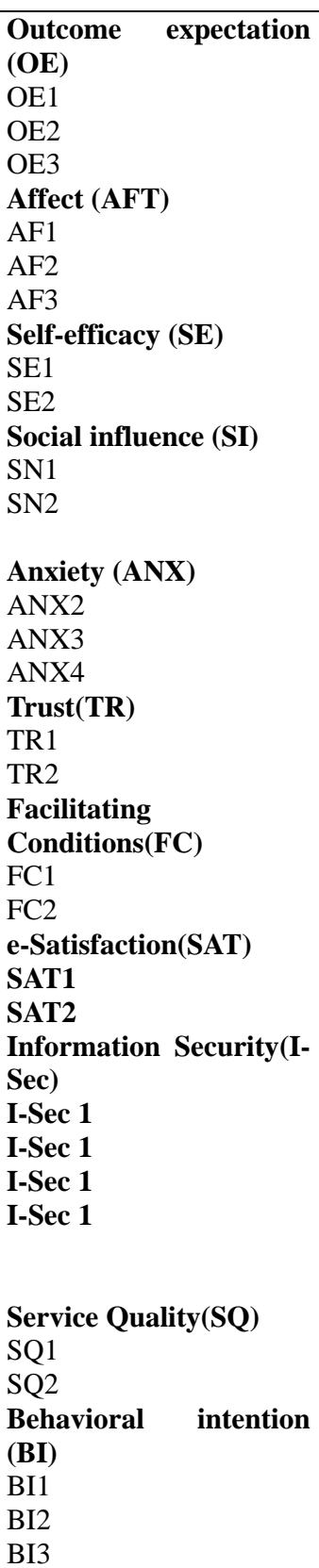 & $\begin{array}{l}0.738 \\
0.735 \\
0.762 \\
\\
0.705 \\
0.699 \\
0.709 \\
\\
0.638 \\
0.641 \\
\\
0.732 \\
0.731 \\
\\
\\
0.721 \\
0.719 \\
0.744 \\
\\
0.721 \\
0.711 \\
\\
0.754 \\
0.765 \\
\\
0.769 \\
0.767 \\
\\
0.699 \\
0.698 \\
0.695 \\
0.693\end{array}$ & $\begin{array}{l}0.701 \\
0.634 \\
0.729 \\
0.738 \\
0.749 \\
0.774 \\
0.768 \\
0.773\end{array}$ & $\begin{array}{l}0.449 \\
0.587 \\
0.589 \\
0.643 \\
0.633 \\
0.623 \\
0.647\end{array}$ \\
\hline
\end{tabular}

Table 6 shows test results to analyze discriminant validity as proposed by Anderson and Gerbing (1988). Squared correlation between a 
pair of potential variables always should be fewer than square root of variance extracted estimate of each variable as mentioned in the table 6 below.

Table 6: Squared pair-wise correlation

\begin{tabular}{|c|c|c|c|c|c|c|c|c|c|c|c|}
\hline Variable & $\mathrm{OE}$ & AFT & SE & SI & ANX & TR & FC & SAT & I-Sec & SQ & BI \\
\hline $\mathrm{OE}$ & $0.801^{\mathrm{a}}$ & & & & & & & & & & \\
\hline AFT & $0.469^{b}$ & $0.713^{\mathrm{a}}$ & & & & & & & & & \\
\hline SE & $0.468^{b}$ & $0.515^{\mathrm{b}}$ & $0.665^{\mathrm{a}}$ & & & & & & & & \\
\hline SI & $0.487^{\mathrm{b}}$ & $0.301^{\mathrm{b}}$ & $0.351^{\mathrm{b}}$ & $0.761^{\mathrm{a}}$ & & & & & & & \\
\hline ANX & $0.205^{\mathrm{b}}$ & $0.128^{\mathrm{b}}$ & $0.169^{\mathrm{b}}$ & $0.302^{\mathrm{b}}$ & $0.768^{\mathrm{a}}$ & & & & & & \\
\hline TR & $0.464^{b}$ & $0.501^{b}$ & $0.349^{b}$ & $0.353^{\mathrm{b}}$ & $0.308^{\mathrm{b}}$ & 0 . & & & & & \\
\hline FC & $0.459^{b}$ & $0.341^{\mathrm{b}}$ & $0.386^{\mathrm{b}}$ & $0.305^{\mathrm{b}}$ & $0.315^{\mathrm{b}}$ & $771^{\mathrm{a}}$ & 0 . & & & & \\
\hline SAT & $0.453^{b}$ & $0.321^{\mathrm{b}}$ & $0.343^{\mathrm{b}}$ & $0.311^{\mathrm{b}}$ & $0.323^{b}$ & $0.313^{\mathrm{b}}$ & $775^{\mathrm{a}}$ & $0.777^{\mathrm{a}}$ & & & \\
\hline I-Sec & $0.467^{\mathrm{b}}$ & $0.401^{\mathrm{b}}$ & $0.403^{b}$ & $0.321^{\mathrm{b}}$ & $0.311^{b}$ & $0.332^{\mathrm{b}}$ & $0.311^{\mathrm{b}}$ & $0.344^{\mathrm{b}}$ & $0.765^{\mathrm{a}}$ & & \\
\hline SQ & $0.451^{\mathrm{b}}$ & $0.469^{b}$ & $0.381^{\mathrm{b}}$ & $0.313^{\mathrm{b}}$ & $0.323^{\mathrm{b}}$ & $0.411^{\mathrm{b}}$ & $0.311^{\mathrm{b}}$ & $0.389^{b}$ & $0.383^{b}$ & $0.719^{a}$ & \\
\hline BI & $0.429^{b}$ & $0.501^{b}$ & $0.409^{b}$ & $0.351^{b}$ & $0.091^{\mathrm{c}}$ & $0.319^{b}$ & $0.517^{\mathrm{b}}$ & $0.365^{b}$ & $0.427^{\mathrm{b}}$ & $0.319^{b}$ & $0.816^{\mathrm{a}}$ \\
\hline & & & & & & $0.343^{\mathrm{b}}$ & $0.299^{\mathrm{b}}$ & & & & \\
\hline
\end{tabular}

a Square root of VEE as given on diagonal.

b Significant at p b 0.01,

c Significant at p b 0.05 .

\subsection{Structural Model Testing}

In Table 7 we illustrate model fit for the structural model testing. In a typical manner research workers inform a number of fit-statistics to investigate the relative fit of data to relevant model and here we suggest goodness of-fit index (GFI), adjusted GFI (AGFI) and comparative fit index (CFI). Gerbing and Anderson (1992) found the CFI as one of the most stable and robust fit indices. We also describe RMSEA (Root Mean Square Error of Approximation) which evaluates the difference per degree of freedom (Steiger and Lind, 1980) and discovered it as similar to the proposed range of values. GFI should be at 0.90 or above 0.90 (Hoyle, 1995) while AGFI should be at 0.80 or above 0.80 (Chin and Todd; 1995, Segars and Grover; 1993). CFI statistics should be at 0.90 or above 0.90 (Bentler and Bonett; 1980, Hoyle; 1995). RMSEA should be in range of $0.05-0.08$ to show rational errors of approximation (Browne and Cudeck; 1993) but has been proposed to correspond a strong good fit if it is beneath the more suppressive threshold of 0.08 (Belanger and Carter, 2008).

Table 7: Model Fit Analysis of Our Proposed Model

\begin{tabular}{|l|l|l|}
\hline Fit index & Structural model & Recommendation \\
\hline Chi-square & 339.234 & N/A \\
Degree of freedom (DF) & 102 & N/A \\
P & 0.001 & $>0.05$ \\
Chi-square/DF & 3.321 & $<2.500$ \\
GFI & 0.894 & $>0.80$ \\
AGFI & 0.891 & $>0.80$ \\
CFI & 0.893 & $>0.80$ \\
RMSEA & 0.077 & $<0.07$ \\
\hline
\end{tabular}


Table 8: Path Coefficients

\begin{tabular}{|c|c|c|c|c|c|}
\hline $\mathrm{H} \#$ & Hypothesis & Coefficients & CRT & Sig. & Supported \\
\hline H1 & Outcome expectation $\rightarrow$ affect & 0.29 & 4.567 & $* * *$ & YES \\
\hline & Affect $\rightarrow$ behavioral intention & 0.53 & 7.768 & $* * *$ & YES \\
\hline $\mathrm{H} 2$ & Social influence $\rightarrow$ behavioral intention & & & & \\
\hline H3 & $\begin{array}{l}\text { Social influence } \rightarrow \text { outcome expectation } \\
\text { Self-efficacy } \rightarrow \text { outcome expectation }\end{array}$ & 0.23 & 4.123 & $* * *$ & YES \\
\hline $\mathrm{H} 4$ & $\begin{array}{l}\text { Self-efficacy } \rightarrow \text { affect } \\
\text { Anxiety } \rightarrow \text { behavioral intention }\end{array}$ & 0.49 & 6.499 & $* * *$ & YES \\
\hline H5 & Trust $\rightarrow$ behavioral intention & 0.41 & 6.119 & $* * *$ & YES \\
\hline H6 & $\begin{array}{l}\text { Facilitating Conditions } \rightarrow \text { behavioral } \\
\text { intention }\end{array}$ & 0.53 & 6.109 & $* * *$ & YES \\
\hline H7 & Satisfaction $\rightarrow$ behavioral intention & -0.14 & -1.877 & * & YES \\
\hline H8 & Information Security $\rightarrow$ Satisfaction & 0.33 & 5.111 & $* * *$ & YES \\
\hline H9 & Service Quality $\rightarrow$ Satisfaction & 0.39 & 5.123 & $* * *$ & YES \\
\hline H10 & & 0.31 & 5.011 & $* * *$ & YES \\
\hline H11 & & 0.32 & 5.121 & $* * *$ & YES \\
\hline H12 & & 0.31 & 5.114 & $* * *$ & YES \\
\hline
\end{tabular}

Fig. 2 shows validated research model.

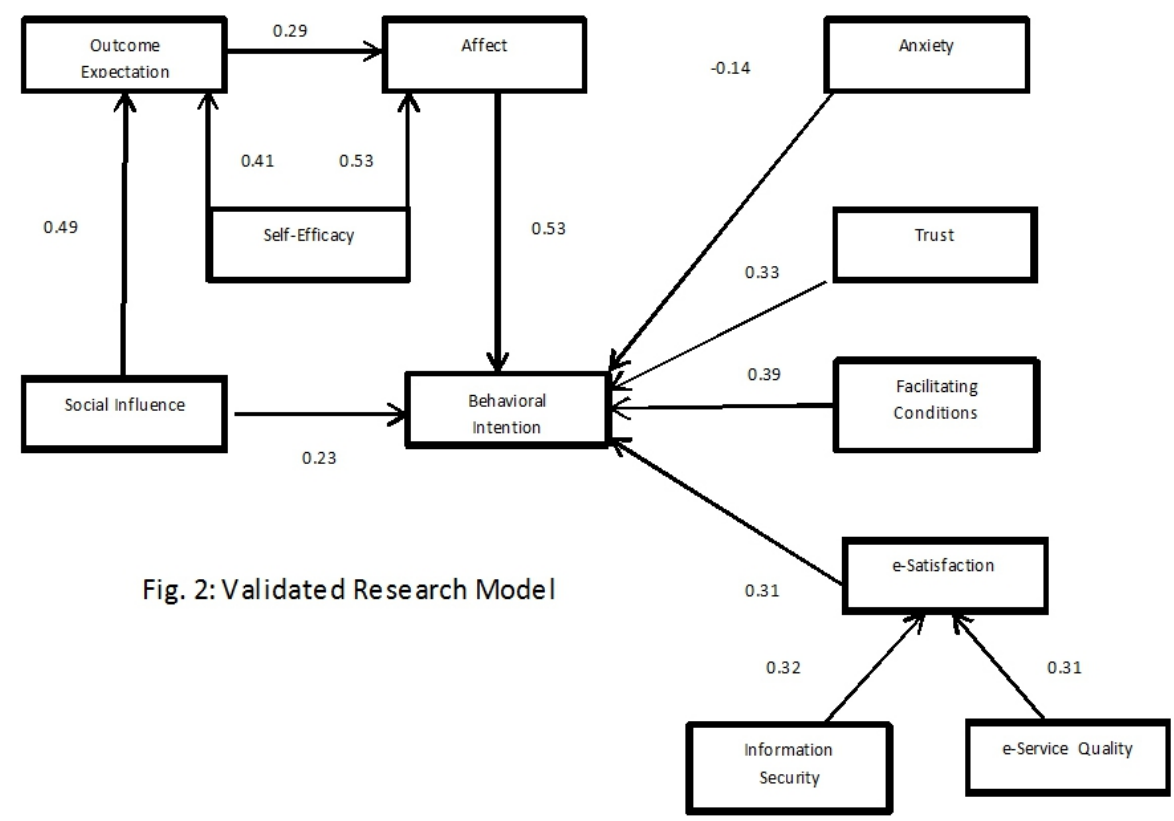

\section{Discussion}

Using the prolonged social cognitive theory objective of this article is to investigate factors impacting the adoption of LRMIS system in context of 
Pakistan. We incorporated constructs social influence, trust, accessibility and service quality in the SCT model to examine our e-government systems. The hypotheses outcomes exhibited that there are noteworthy linkages for all structural relations supporting relevant hypotheses. Significant impact of outcome expectation affect is very similar like positive and significant impact of the similar kind of constructs such as performance expectancy or perceived usefulness on attitude. Outcome expectation in our proposed model is attached to user's personal aspects as it shows citizen' s increased efficiency, capability to enhance quantity and quality of related output for same amount of effort by using the LRMIS system and its positive impact on attitude. Self-efficacy discovered to have a vital and significance relations showing that even users who are not much used to the LRMIS system but their comfort level with other relevant information and e-government systems help them to maintain a positive attitude toward using LRMIS system. Social influence was discovered to impact noteworthy on both behavioral intention and outcome expectation. Noteworthy impact of effect on behavioral Intention shows that citizens having stronger attitude towards LRMIS are more eager and likely to actually use the system. In our article a vital and positive relation between attitude and behavioral intention shows that positive affect to use the LRMIS system directs citizens to strongly produce favorable intentions to use it. Anxiety is a very direct and vital forecaster of behavioral intention discovered. Trust also impact directly and positively on behavioral intentions. Accessibility has a deep and direct influence of behavioral intentions on citizens to adopt LRMIS. Service quality also impact directly and positively on the behavioral intentions of citizens to adopt LRMIS. SCT model with some addition of constructs is validated for the very first time in context to Pakistan on e-government adoption. Our research has provided an opportunity for E-government researchers to investigate factors influencing the adoption intentions of LRMIS and some similar systems which would develop in near future in developing countries like Pakistan. Final results of the hypotheses attached to the suggested model would assist researchers toward a deep knowledge and realization of citizen's behavioral intention of LRMIS. Outcomes will allow e-government managers to recognize the factors to understand for enhancing the citizen's behavioral intentions of LRMIS.

\section{References:}

Ajzen, I. (1991). The theory of planned behavior. Organizational Behavior and Human Decision Processes, 50(2), 179 - 211.

Al-Shafi, S., \& Weerakkody, V. (2010). Factors affecting e-government adoption in the state of Qatar. European and Mediterranean Conference on Information Systems, Abu Dhabi, UAE. 
Anderson, J.C., \& Gerbing, D.W. (1988). Structural equation modeling in practice: A review and recommended two-step approach. Psychological Bulletin, 103(3), 411 - 423.

Anthopoulos, L.G., Siozos, P., \& Tsoukalas, I.A. (2007). Applying participatory design and collaboration in digital public services for discovering and re-designing e-government services. Government Information Quarterly, 24(2), 353 - 376.

Bandura, A. (1986). Social foundations of thought and action: A social cognitive theory. Englewood Cliffs, NJ: Prentice-Hall.

Barclay, D.W., \& Smith, J.B. (1997). The effects of organizational differences and trust on the effectiveness of selling partner relationships. Journal of Marketing, 61(1), 3 - 21.

Belanger, F., \& Carter, L. (2008). Trust and risk in e-government adoption. The Journal of Strategic Information Systems, 17(2), 165 - 176.

Bentler, P., \& Bonett, D. (1980). Significance tests and goodness of fit in the analysis of covariance structures. Psychological Bulletin, 88(3), 588 - 606.

Browne, M.W., \& Cudeck, R. (1993). Alternative ways of assessing model fit. In K.A. Bollen, \& S. Long (Eds.), Testing structural equation models (pp. 136 - 162). Newbury Park, CA: Sage.

Carter, L., Schaupp, L.C., \& Evans, A. (2008). Antecedents to e-file adoption: The US perspective. Hawaii International Conference on System Sciences $(216$ - 216).

Carter, L., Schaupp, L.C., \& McBride, M.E. (2011). The US e-file initiative: An investigation of the antecedents to adoption from the individual taxpayers' perspective. e-Service Journal, 7(3), 2 - 19.

Chiang, L. (2009). Trust and security in the e-voting system. Electronic Government, an International Journal, 6(4), 343 - 360.

Chin, W.W., \& Todd, P.A. (1995). On the use, usefulness, and ease of use of structural equation modeling in MIS research: A note of caution. MIS Quarterly, 19(2), 237 - 246.

Chu, P. -Y., Hsiao, N., Lee, F.W., \& Chen, C.W. (2004). Exploring success factors for Taiwan's government electronic tendering system: Behavioral perspectives from end users. Government Information Quarterly, 21(2), $219-234$.

Coulter, K., \& Coulter, R. (2002). Determinants of trust in a service provider: The moderating role of length of relationship. Journal of Services Marketing, 16(1), 35 - 5

Compeau, D.R., \& Higgins, C.A. (1995). Computer self-efficacy: Development of a measure and initial test. MIS Quarterly, 19(2), 189 - 211. Davis, F.D. (1989). Perceived usefulness, perceived ease of use, and user 
acceptance of information technology. MIS Quarterly, 13(3), 319 - 339.

Davis, F.D., Bagozzi, R.P., \& Warshaw, P.R. (1989). User acceptance of computer technology: A comparison of two theoretical models. Management Science, 35(8), 982 - 1002.

DeLone, W.H., \& McLean, E.R. (1992). Information systems success: The quest for the dependent variable. Information Systems Research, 3(1), 60 95.

DeLone, W.H., \& McLean, E.R. (2003). The DeLone and McLean model of information systems success: A ten-year update. Journal of Management Information Systems, 19(4), 9 - 30.

E-Government (September 1). E-government. (from). http://en.wikipedia.org/wiki/

Mobile government

Ekici, A., \& Peterson, M. (2009). The unique relationship between quality of life and consumer trust in market-related institutions among financially constrained consumers in a developing country. Journal of Public Policy \& Marketing, 28(1), 56 - 70.

Fagan, M.H., Neill, S., \& Wooldridge, B.R. (2003). An empirical investigation into the relationship between computer self-efficacy, anxiety, experience, support and usage. Journal of Computer Information Systems, 44(2), 95 - 104.

Fishbein, M., \& Ajzen, I. (1975). Belief, attitude, intention and behavior: An introduction to theory and research. Reading, MA: Addison-Wesley.

Floropoulos, J., Spathis, C., Halvatzis, D., \& Tsipouridou, M. (2010). Measuring the success of the Greek Taxation Information System. International Journal of Information Management, 30(1), 47 - 56.

Fornell, C., \& Larcker, D.F. (1981). Evaluating structural equation models with unobservable variables and measurement error. Journal of Marketing Research, 18(1), 39 - 50.

Fotland, A.I. (2012). Intention to use RFID-enabled services: Theoretical review and case study. MSc Dissertation Bergen: NHH.

Gao, T., \& Deng, Y. (2012). A study on users' acceptance behavior to mobile e-books application based on UTAUT model. 3rd International Conference on Software Engineering and Service Science (pp. 376 - 379).

Gefen, D. (2000). E-commerce: The role of familiarity and trust. Omega: The International Journal of Management Science, 28(6), 725 - 737.

Gerbing, D.A., \& Anderson, J.C. (1992). Monte Carlo evaluations of goodness of fit indices for structural equation models. Sociological Methods and Research, 2(2), 132 - 160.

Gorla, N. (2008). Hurdles in rural e-government projects in India: Lessons 
for developing countries. Electronic Government, an International Journal, 5(1), 91 - 102 .

Gorla, N. (2009). A survey of rural e-government projects in India: Status and benefits. Information Technology for Development, 15(1), 52 - 58.

Gummerus, J., Liljander, V., Pura, M., \& Van Riel, A. (2004). Customer loyalty to content based web sites: The case of an online health-care service. Journal of Services Marketing, 18(3), 175 - 186.

Hair, J.F., Anderson, R.E., Tatham, R.L., \& Black, W.C. (1992). Multivariate data analysis with readings (3rd ed.). New York, NY: Macmillan Publishing Company.

Henry, S. L. (2006). Introduction to web accessibility. Retrieved July 15, 2011, from.

www.w3c.org/WAI/intro/accessibility.php

Hoyle, R.H. (1995). The structural equation modeling approach: Basic concepts and fundamental issues. Thousand Oaks, CA: Sage.

Hu, L. -T., \& Bentler, P.M. (1999). Cutoff criteria for fit indexes in covariance structure analysis: Conventional criteria versus new alternatives. Structural Equation Modeling, 6, 1 - 55.

Hu, P.J.H., Chen, H., Hu, H.F., Larson, C., \& Butierez, C. (2011). Law enforcement officers' acceptance of advanced e-government technology: A survey study of COPLINK mobile. Electronic Commerce Research and Applications, 10(1), 6 - 16.

Hung, S.Y., Chang, C.M., \& Yu, T. (2006). Determinants of user acceptance of the e-government services: The case of online tax filing and payment system. Government Information Quarterly, 23(1), 97 - 122.

Hung, S. -Y., Tang, K. -Z., Chang, C. -M., \& Ke, C. -D. (2009). User acceptance of intergovernmental services: An example of electronic document management system. Government Information Quarterly, 26(2), 387 - 397.

Igbaria, M., \& Iivari, J. (1995). The effects of self-efficacy on computer. Omega, 23, 587 - 605.

J. Krogstie, Requirements engineering for mobile information systems, in: the Seventh International Workshop on Requirements Engineering: Foundations for Software Quality (REFSQ' 01), Interlaken, Switzerland, 2001.

Jaeger, P.T. (2003). The endless wire: E-government as global phenomenon. Government Information Quarterly, 20(4), 323 - 331.

Kim, H.J., Pan, G., \& Pan, S.L. (2007). Managing IT-enabled transformation in the public sector: A case study on e-government in South Korea. Government Information 
Quarterly, 24(2), 338 - 352.

Kim, D. J., Donald, L. F., \& Raghav Rao, H. (2009). Trust and satisfaction, two stepping stones for successful e-Commerce relationships: A longitudinal exploration. Information Systems Research, 20(2), 237 - 257

Koh, C.E., Prybutok, V.R., Ryan, S.D., \& Wu, Y. (2010). A model for mandatory use of software technologies: An integrative approach by applying multiple levels of abstraction of informing science. Informing Science: The International Journal of an Emerging Transdiscipline, 13, 177 - 203.

L.-D. Chen, A model of consumer acceptance of mobile payment, Int J Mob Commun 6 (2008), 32 - 52.

Lee, G., \& Lin, H. (2005). Customer perceptions of e-service quality in online shopping.International Journal of Retail and Distribution Management, 33(2), 161 - 176.

Liu, Y., Li, H., Kostakos, V., Goncalves, J., Hosio, S., \& Hu, F. (2014). An empirical investigation of mobile government adoption in rural China: A case study in Zhejiang province. Government Information Quarterly, 31(3), 432 442.

Loo, W.H., Paul, H.P., Yeow, P.H.P., \& Chong, S.C. (2009). User acceptance of Malaysian government multipurpose smartcard applications. Government Information Quarterly, 26(2), 358 - 367.

Lu, C. -T., Huang, S. -Y., \& Lo, P. -Y. (2010). An empirical study of on-line tax filing acceptance model: Integrating TAM and TPB. African Journal of Business Management, 4(5),800 - 810.

Martinez, J.A., Pfeffer, K.H., \& van Dijk, T. (2009). The capacity of egovernment tools: Claimed potentials, unnamed limitations. Proceeding of the 10th N-AERUS Conference: Challenges to Open Cities in Africa, Asia, Latin America and the Middle East: Shared Spaces Within and Beyond. Rotterdam: IHS.

Mcknight, D., Choudhury, V., \& Kacmar, C. (2002). Developing and validating trust measures for e-commerce: An integrative typology. Information Systems Research, 13(3), 334 - 359

Moon, J. (2002). The evolution of e-Government among municipalities: Rhetoric or reality? Public Administration Review, 62(4).

Netemeyer, R., Bearden, W., \& Sharma, S. (2003). Scaling procedures: Issues and applications. Thousand Oaks, CA7 Sage.

Netemeyer, R.G., Johnston, M.W., \& Burton, S. (1990). Analysis of role conflict and role ambiguity in a structural equations framework. Journal of Applied Psychology, 75(2), 148 - 157.

Or, C.K., Karsh, B.T., Severtson, D.J., Burke, L.J., Brown, R.L., \& Brennan, P.F. (2011). Factors affecting home care patients' acceptance of a web-based 
interactive self-management technology. Journal of the American Medical Informatics Association, 18(1), 51 - 59.

P. Luarn and H.-H. Lin, toward an understanding of the behavioral intention to use mobile banking, Computers in Human Behavior 21 (2005), 873 - 891. Pagani, M., Hofacker, C.F., \& Goldsmith, R.E. (2011). The influence of personality on active and passive use of social networking sites. Psychology \& Marketing, 28(5), 441 - 456.

Park, C., \& Kim, Y. (2003). Identifying key factors affecting consumer purchase behavior in an online shopping context. International Journal of Retail \& Distribution Management, 31(1), 16 - 29.

Rana, N.P., Dwivedi, Y.K., Williams, M.D., \& Lal, B. (2015). Examining the success of the online public grievance redressal systems: An extension of the IS success model. Information Systems Management, 32, 1 - 21

Rana, N.P., Dwivedi, Y.K., Williams, M.D., \& Weerakkody, V. (2014). Investigating success of an e-government initiative: Validation of an integrated IS success model. Information Systems Frontiers, 1 - 16.

Rana, N., Williams, M., \& Dwivedi, Y. (2013). Examining factors affecting adoption of online public grievance redressal system: A case of India. UK: UKAIS, University of Oxford.

Rao, T.P.R. (2004). ICT and e-governance and for rural development. Symposium on governance in development: Issues, challenges, and strategies. India: Institute of Rural Management.

Rogers, E. M. (1995). Diffusion of Innovations (Fourth Ed.). New York: The Free Press.

Roy, M., Dewit, O., \& Aubert, B. (2001). The impact of interface usability on trust in web retailers. Internet Research, 11(5), 388 - 398

Rust, R., \& Lemon, J. (2009). E-Service and the consumer. International Journal of Electronic Commerce, 5(3), 83 - 99.

Sahu, G.P., \& Gupta, M.P. (2007). Users' acceptance of e-government: A study of Indian central excise. International Journal of Electronic Government Research, 3(3), 1 - 21.

Santos-Vijande, M.L., López-Sánchez, J.Á., \& Trespalacios, J.A. (2012). How organizational learning affects a firm's flexibility, competitive strategy, and performance. Journal of Business Research, 65(8), 1079 - 1089.

Segars, A. H., \& Grover, V. (1993). Re-examining perceived ease of use and usefulness: A confirmatory factor analysis. MIS quarterly, 517 - 525.

Seyal, A.H., \& Pijpers, G.G.M. (2004). Senior government executives' use of the Internet: A Bruneian scenario. Behaviour \& Information Technology, 23(3), $197-210$.

S.J. Barnes, The mobile commerce value chain: Analysis and future 
developments, International Journal

of Information Management 22(2002),91-108

Staples, D.S., Hulland, J.S., \& Higgins, C.A. (1999). A self-efficacy theory explanation for the management of remote workers in virtual organizations. Organization Science, 10(6), 758 - 776.

Steiger, J.H., \& Lind, J.C. (1980). Statistically-based tests for the number of common factors. Paper presented at the Annual Spring Meeting of the Psychometric Society, Iowa City.

Susanto, T.D., \& Goodwin, R. (2013). User acceptance of SMS-based egovernment services: Differences between adopters and non-adopters. Government Information Quarterly, 30(4), 486 - 497.

Taylor, S., \& Todd, P.A. (1995a). Understanding information technology usage: A test of competing models. Information Systems Research, 6(2), $144-176$.

Taylor, S., \& Todd, P.A. (1995b). Decomposition and crossover effects in the theory of planned behaviour: A study of consumer adoption. International Journal of Research in Marketing, 12(2), 137 - 155.

Tohidinia, Z., \& Mosakhani, M. (2010). Knowledge sharing behaviour and its predictors. Industrial Management \& Data Systems, 110(4), 611 - 631.

Venkatesh, V., Morris, M.G., Davis, G.B., \& Davis, F.D. (2003). User acceptance of information technology: Toward a unified view. MIS Quarterly, 27(3), 425 - 478.

Venkatesh, V., Sykes, T.A., \& Venkatraman, S. (2014). Understanding egovernment portal use in rural India: Role of demographic and personality characteristics. Information Systems Journal, 24(3), 249 - 269.

Venkatesh, V., Thong, J.Y., Chan, F.K., Hu, P.J.H., \& Brown, S.A. (2011). Extending the two - stage information systems continuance model: Incorporating UTAUT predictors and the role of context. Information Systems Journal, 21(6), 527 - 555.

Wang, Y. -S. (2002). The adoption of electronic tax filing systems: An empirical study. Government Information Quarterly, 20(4), 333 - 352.

Wang, Y. -S., \& Liao, Y. -W. (2008). Assessing e-Government systems success: A validation of the DeLone and McLean model of information systems success. Government Information Quarterly, 25(4), 717 - 733.

The World Bank: Land Records Management and Information Systems Program (LRMIS-P) Province of Punjab (P090501)

Ye, S., Chen, H., \& Jin, X. (2006). An empirical study of what drives users to share knowledge in virtual communities. In J. Lang, F. Lin, \& J. Wang (Eds.), Knowledge science. Engineering and Management. (pp. 563 - 575). Berlin: Springer. 
Zikmund, W.G. (1994). Business research methods (4th Ed.). New York, NY: The Dryden Press.

\section{Appendix A. Description of the final survey items}

\section{Outcome Expectation (OE)}

OE1. If I use mobile LRMIS, I will increase my effectiveness.

OE2. If I use mobile LRMIS, I will increase the quality of output.

OE3. If I use mobile LRMIS, I will increase the quantity of output for the same amount of effort.

Affect (AFT)

AF1. I would like see my land records using the mobile LRMIS.

AF2. I look forward to those aspects of observing my land records that require me to use mobile LRMIS.

AF3. Using the mobile LRMIS would be interesting to me.

Self-Efficacy (SE)

SE1. I would feel comfortable while using mobile LRMIS on my own.

SE2. If I wish, I could easily operate mobile LRMIS on my own.

Anxiety (ANX)

ANX1. It frightens me to think that I could lose my land information using mobile LRMIS by hitting the wrong key.

ANX2. I hesitate to use the mobile LRMIS for fear of making mistakes I cannot correct.

ANX3. mobile LRMIS would be somewhat intimidating to me.

Social influence (SI)

SN1. People who influence my behavior think that I should use mobile LRMIS.

SN2. People who are important to me think that I should use mobile LRMIS.

SN3. I would use mobile LRMIS because of the certain section of people who use the system.

Trust (TR)

TR1: I can always trust LRMIS services.

TR2: LRMIS implementation is the right Government policy.

Facilitating Conditions (FC)

FC1: Better organizational and technical infrastructures strongly motivate me to use m LRMIS.

FC2: Good infrastructural facilities would always increase my efficiency to use $\mathrm{m}$ LRMIS. 
e-Satisfaction (SAT)

(SAT1) I am highly satisfied by the LRMIS services.

(SAT2) After using, LRMIS I always feel high level of satisfaction

Information Security (I-Sec)

(I-Sec1) Online mobile land record activities while using LRMIS are secure.

(I-Sec2) I worry about information security while using LRMIS.

(I-Sec3) I have confidence in LRMIS.

(I-Sec4) While looking at my data on LRMIS, I worry about its accuracy.

e-Service Quality (e-SQ)

e-SQ1: I think service quality of mobile LRMIS is very good.

e-SQ2: People who are important to me also think that service quality of mobile LRMIS is very good.

Behavioral intention (BI)

BI1. I intend to use mobile LRMIS.

BI2. I predict that I would use mobile LRMIS.

BI3. I plan to use mobile LRMIS in the near future. 